http://dx.doi.org/10.32929/2446-8355.2018v27n4p440-449

\title{
BEHAVIOR OF WATER IN SOIL CULTIVATED WITH SUNFLOWER UNDER WATER STRESS ${ }^{1}$
}

\author{
Marconi Seabra Filho ${ }^{2}$, Ademir Silva Menezes ${ }^{3 *}$, Luís Gonzaga Pinheiro Neto ${ }^{4}$, Benito \\ Moreira Azevedo ${ }^{5}$, Thales Vinicius de Araújo Viana ${ }^{6}$, George Martins Sampaio ${ }^{7}$
}

2 Docente, Instituto Federal de Educação, Ciência e Tecnologia do Ceará (IFCE), Sobral, Ceará.

${ }^{3}$ Docente, Faculdade Ieducare (FIED), Tianguá, Ceará.*E-mail: amenezzes@gmail.com.

${ }^{4}$ Docente, Instituto Federal de Educação, Ciência e Tecnologia do Ceará, Sobral, Ceará.

${ }^{5}$ Docente, Universidade Federal do Ceará, Fortaleza, Ceará.

${ }^{6}$ Docente, Universidade Federal do Ceará, Fortaleza, Ceará.

${ }^{7}$ Docente, Instituto Federal de Educação, Ciência e Tecnologia do Ceará, Sobral, Ceará.

Recebido: 30/01/2018; Aceito: 14/12/2018

\begin{abstract}
Various soil attributes allow inferring about their behavior and function in the environment. With this work, the objective was to analyze the behavior of water retention in the soil after irrigation suppression for the BRS 323 hybrid sunflower cultivation in a sandy loam soil. The experiment was conducted at the Agrometeorological Station of the Federal University of Ceará, Brazil, from August to November, 2015. The behavior of soil water was evaluated by means of the retention curve, available water content, grain size, total porosity, and soil particle density in the 0.0 to $0.20 \mathrm{~m}$ soil layer. The water in the depth of $0.0-0.10 \mathrm{~m}$ drains rapidly in relation to the $0.10-0.20 \mathrm{~m}$ depth between potentials from -0.1 to -1.500 $\mathrm{kPa}$ after irrigation suppression, in this depth, at $-4 \mathrm{kPa}$, there was greater water retention along the curve. The maximum water retained in the soil at field capacity in the layer depths of $0.0-0.10 \mathrm{~m}$ and $0.10-0.20 \mathrm{~m}$ is: $0.195 \mathrm{~cm}^{3} \mathrm{~cm}^{-3}$ and $0.221 \mathrm{~cm}^{3} \mathrm{~cm}^{-3}$, respectively. The $0.10-0.20 \mathrm{~m}$ depth presented a larger volume of available water influenced by density and porosity. It was concluded that the water in the soil cultivated with sunflower, 80 days after the irrigation ceases, gradually drains into larger pores, then retained in the smaller pores, being limited to the plants in the soil layer.
\end{abstract}

Key words: Structure of soil. Physical attributes. Soil-water retention curve. Irrigation management.

\section{COMPORTAMENTO DA ÁGUA EM SOLO CULTIVADO COM GIRASSOL SOB ESTRESSE HÍDRICO}

RESUMO: Texto Vários atributos do solo permitem inferir sobre seu comportamento e função no meio ambiente. Com este trabalho o objetivo foi analisar o comportamento da retenção de água no solo após a supressão da irrigação para o cultivo de girassol híbrido 'BRS 323' em solo de textura franco-arenosa. O experimento foi realizado na Estação Agrometeorológica da Universidade Federal do Ceará, Brasil, de agosto a novembro de 2015. O comportamento da água do solo foi avaliado por meio da curva de retenção, teor de água

\footnotetext{
${ }^{1}$ Este trabalho é parte da Tese do primeiro autor.
} 
disponível, granulometria, porosidade total, densidade do solo e de partículas na camada de solo 0,0 a $0,20 \mathrm{~m}$. A água na profundidade de 0,0 a $0,10 \mathrm{~m}$ drena rapidamente em relação à profundidade de 0,10 a 0,20 m entre potenciais de $-0,1$ a $-1.500 \mathrm{kPa}$ após a supressão de irrigação, a esta profundidade, a $-4 \mathrm{kPa}$, houve maior água retenção ao longo da curva. A água máxima retida no solo na capacidade de campo nas profundidades da camada de 0,0 - 0,10 m e 0,10 - 0,20 m é: $0,195 \mathrm{~cm}^{3} \mathrm{~cm}^{-3}$ e $0,221 \mathrm{~cm}^{3} \mathrm{~cm}^{-3}$, respectivamente. A profundidade de 0,10 a $0,20 \mathrm{~m}$ apresentou um volume maior de água disponível influenciada pela densidade e porosidade. Concluiu-se que a água no solo cultivada com girassol, 80 dias após cessar a irrigação, drena gradualmente para poros maiores, retida nos poros menores, sendo limitada às plantas na camada do solo.

Palavras-chave: Estrutura do solo. Atributos físicos. Curva de retenção de água no solo. Manejo da irrigação.

\section{INTRODUCTION}

Several soil attributes allow knowing about its behavior and role in the environment, among all, changes occurring from agricultural management practices. Thus, soil attributes are important for decision making regarding the rational management of soil and water in irrigated agriculture.

It is well known that the pressure for food is higher and higher globally, due to the demographic increase. In order to supply food demand, today's irrigation practice has been successful. According to Mantovani et al. (2009), irrigated agriculture has allowed to optimize the world food production, therefore, it is necessary to know the determining factors in the irrigation management that directly interfere in the water consumption, as well as its storage in the soil (SILVA et al., 2010), which makes irrigation a practice that increases productivity and improve product quality, with prospects of better prices in the market (SILVA et al., 2007; LIMA JUNIOR et al., 2011) and even in storage time.

In the agricultural context, the entry of water into the soil system is due to rainfall and/or irrigation. These two factors are the main promoters of vegetative development, however, it must be stored and available to plants.

Water retention in the soil is represented by the water retention curve (MENEZES et al., 2018), which describes the amount of water retained in the soil in equilibrium at a given matric potential and is considered an important tool in the study of soils attributes (MELO et al., 2014).

The soil water retention curve is also fundamental in studies of water balance and availability to plants, water and solutes dynamics in soil, infiltration and irrigation management (TORMENA e SILVA, 2002). The determination of the soil water retention curve is important for the irrigation area, as well as for soil water dynamics studies, since it provides soil water content $(\theta)$ at different matric potential $(\Psi)$ and vice-versa, thus allowing inferring the soil water content and other variables necessary for the irrigation 
watermanagement, as well as the quantification of the dynamic processes involving the soilplant-atmosphere system (COSTA et al., 2008).

Based on this perspective, Carneiro (2011) affirms that it is important to carry out studies aiming to induce the sunflower plant and others to the water deficit throughout its different development stages in order to identify among them, which is the most sensitive to the effects of irrigation suppression, analyzing the physiological processes of the plant, in order to identify the best management practice.

Thus, Gomes et al. (2003), demonstrated that the mass of 1000 seeds (achenes) increased with decrease of the water deficit in the sunflower cultivar M 742 and Viana et al. (2012) reported that the lower values of plant height and diameter of sunflower stem in the semi-arid region of Ceará, Brazil, under low irrigation levels occurred due to the fact that the water deficit caused stomata closure, a fact that compromised the physiological activities of the plants.

According to Castro et al. (2005) sunflower plant requires low temperatures, especially when there is low water availability. For Castro and Farias (2005), the water requirement grows according to the plant development, requiring 0.5 to $0.7 \mathrm{~mm}$ water depth per day at emergence and requires a maximum of 6 to $8 \mathrm{~mm}$ depth of water per dayat flowering and filling of the grains. This plant can be cultivated throughout the year, provided water availability (LEITE, 2005). Thus, EMEPA (2007) recommend for irrigation system producers the supply of water by irrigation during germination until flowering for good grain formation and considerable oil content.

Sunflower plants respond significantly well to soil water availability by irrigation, given the results demonstrated by the authors such as Acosta (2009), Gomes et al. (2003) and Silva et al. (2007) when studying the relationship between irrigation and productivity could verify such behavior.

With his work, the objective was to analyze the behavior of water retention in the soil after suppression of irrigation in the sunflower (Helianthus annuus L.) hybrid 'BRS 323' in a franco-sandy soil in Ceara State, Brazil.

\section{MATERIALS AND METHODS}

The experiment was conducted in the experimental area of the Federal University of Ceará, UFC Agrometeorological Station in Fortaleza, Brazil, whose geographic coordinates are $3^{\circ} 44^{\prime} 45$ "S and $38^{\circ} 34^{\prime} 55^{\prime \prime} \mathrm{W}$ with an altitude of $19 \mathrm{~m}$, from August to November, 2015, considering the absence of rainfall in this period. According to Köppen (1923) climate classification, the area of the experiment is located in a region of Aw' climate, characterized as tropical rainy (average annual precipitation of $1.523 \mathrm{~mm}$ ). The mean average climate data during the study were: Temperature: $26.9{ }^{\circ} \mathrm{C}$, relative humidity: $73.5 \%$, wind velocity: $4.1 \mathrm{~m}$ $\mathrm{s}^{-1}$ and rainfall in the experiment period: $8.7 \mathrm{~mm}$.

The soil classification of the experiment area according to Embrapa (2013) is a RedYellow Alfisol, whose textural class is sandy-loam. Soil sampling was performed at depths of 
0.0 to $0.20 \mathrm{~m}$, divided into two layers: $0.0-0.10 \mathrm{~m}$ and $0.10-0.20 \mathrm{~m}$. The samples were collected with a dutch type collector auger and then submitted to the procedures of particle size analysis by pipette method (Table 1) and particle density determined by the volumetric displacement method.

Table 1. Soil texture analysis of the experimental area collected at a depth of $0.0-0.20 \mathrm{~m}$.

\begin{tabular}{lcc}
\hline Soil texture & Values & Textural classification \\
\hline Coarse sand $\left(\mathrm{g} \mathrm{kg}^{-1}\right)$ & 412 & \\
Fine sand $\left(\mathrm{g} \mathrm{kg}^{-1}\right)$ & 382 & \\
Percent sand $\left(\mathrm{g} \mathrm{kg}^{-1}\right)$ & 794 & Sandy loam \\
Silt $\left(\mathrm{g} \mathrm{kg}^{-1}\right)$ & 116 & \\
Clay $\left(\mathrm{g} \mathrm{kg}^{-1}\right)$ & 90 & \\
Natural clay $\left(\mathrm{g} \mathrm{kg}^{-1}\right)$ & 79 & \\
\hline
\end{tabular}

Soil bulk density was determined from samples with preserved structure, the samples were dried at $105{ }^{\circ} \mathrm{C}$ until constant mass. The total porosity was obtained from soil and particle density, according to the equation:

$$
\alpha=1-\left(\frac{\rho s}{\rho p}\right)
$$

Where:

$\alpha$ is total porosity $\left(\mathrm{cm}^{3} \mathrm{~cm}^{-3}\right), \rho$ and $\rho p$ the bulk and particle density $\left(\mathrm{g} \mathrm{cm}^{-3}\right)$, respectively.

The microporosity was determined considering the pores with diameter $<50 \mu \mathrm{m}$ from the application of the matric potential of $-6 \mathrm{kPa}$ (Danielson \& Sutherland, 1986) and macroporosity was determined by difference between total porosity and microporosity.

Irrigation suppression was analyzed for six different time periods, with seven days interval each, cancelling the irrigation until the end of the sunflower (Helianthus annuus) phenological cycle for the hybrid 'BRS 323'. The treatments corresponding to irrigation suppression were: 45, 52, 59, 66, 73 and 80 days after sowing, whose water blade was 225.05, 290.78, 354.83, 417.04, 480.96 and $528.87 \mathrm{~mm}$, respectively.

The irrigation system adopted was a drip irrigation system. The irrigation depth was determined by the "Class A" evaporation methodology located at the meteorological station of the Federal University of Ceará, Brazil, $80 \mathrm{~m}$ distant from the experiment, whose purpose was to replace the water lost by the plant evapotranspiration using the crop coefficient $(\mathrm{Kc})$ according to the development stage of the plant, and relative humidity and wind velocity parameters at the site.

The soil water retention characteristic curve was determined 80 days after sowing (coinciding with 80 days of irrigation suppression). Two samples were collected using Uhland-type samples at depths of $0,0-0.10$ and $0.10-0.20 \mathrm{~m}$ maintaining the soil structure preserved.

In order to determine the soil water retention curve the samples were saturated with water for 24 hours and then submitted to different potentials $(\Psi \mathrm{m})$ in pressure using the 
Richards methodology system, according to the method described by Embrapa (2011). With the soil water curve, the total available water (TAW) was obtained mathematically, considering the value of moisture in the field capacity subtracted from the wilting point value and multiplied by the depth in millimeters.

The data obtained from the soil water retention curve (physical parameters) were submitted to descriptive statistical analysis for two soil samples collected at depths of $0.0-$ 0.10 and $0.10-0,20 \mathrm{~m}$, thus using the mean values, standard deviation, variance and coefficient of variation were determined.

\section{RESULTS AND DISCUSSION}

Figure 1 shows the behavior of water retention in the soil along the soil layer ranging from $0.0-0.20 \mathrm{~m}$. It is noted that water in the depth of $0.0-0.10 \mathrm{~m}$ drains rapidly in relation to the depth of $0.10-0.20 \mathrm{~m}$ between potentials of -0.1 to $-1.500 \mathrm{kPa}$ as irrigation ceases, this is due to the sand percentage $\left(794 \mathrm{~g} \mathrm{~kg}^{-1}\right.$ ) and the sandy-loam texture (Table 1), which influences the water drainage through the soil. This behavior is in accordance to Dexter (2004), when the author states that the process of water drainage starts first in the larger pores and then in the micropores. With respect to the layer of $0.10-0.20 \mathrm{~m}$, it was observed that from the potential of $-4 \mathrm{kPa}$ and lower there was greater water retention along the curve for this layer in relation to the first depth (Figure 1). This is explained by the less volume of pores for this layer $\mathrm{m}\left(0.319 \mathrm{~cm}^{3} \mathrm{~cm}^{-3}\right)$ which is reduced in depth, seeing by the smoothing of the curve.

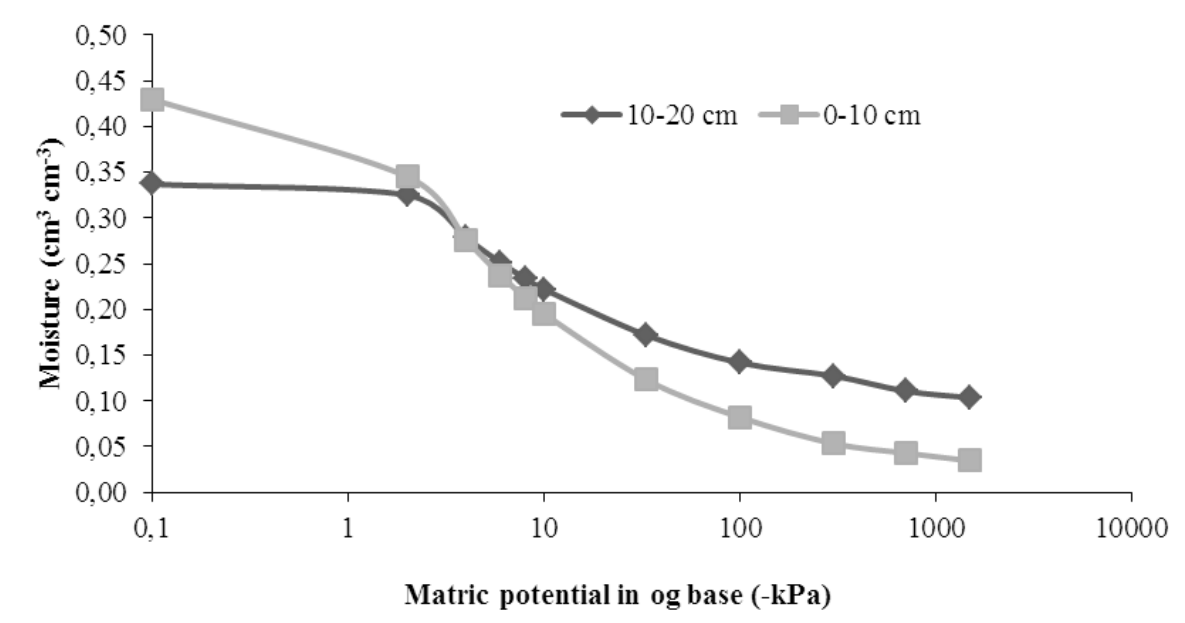

Figure 1. Retention curve of the soil after irrigation suppression in sunflower cultivation.

In this case, considering that the highest water retention after cessation of irrigation occurred at a depth of 0.10 to $0.20 \mathrm{~m}$, in a range of matric potential between $-4 \mathrm{kPa}$ and -1500 $\mathrm{kPa}$, it is worth mentioning that this behavior is important to the water requirement of the cultivated plant, since it is an edaphic layer, where most of the root system is concentrated, thus facilitating the absorption of the soil solution. This fact can also be justified by the greater volume of micropores $\left(0.251 \mathrm{~cm}^{3} \mathrm{~cm}^{-3}\right)$ observed at that depth, as well as the porous arrangement and the strength with which water is retained in these capillaries (MENEZES et al., 2018). According to Tuller and Or (2003), the water retention curve in the soil is a 
hydraulic property that is related to pores size and connectivity, thus confirming that water movement along the soil profile is strongly affected mainly by the texture of the soil and its structure.

The movement of water in the soil in which the plant is being cultivated is affected by several factors: soil, plant and the atmosphere, however, in the present work, the approach was made only considering some soil parameters, among which is the relation between soil moisture $(\theta)$ and the matric potential $(\Psi \mathrm{m})$, represented by the characteristic or retention curve in the soil. However, according to Reichardt and Timm (2012), it is important to emphasize that the process of water loss by plants must consider the soil-plant-atmosphere system.

In the case of soil moisture at the field capacity, whose matric potential is observed at $10 \mathrm{kPa}$ according to Silva et al. (1994), evaluated at two depths, conceptually refers to the soil water balance between the potential $(\Psi \mathrm{m})$ and the gravitational potential $(\mathrm{Yg})$, the time when the water in the soil profile stops draining. Based on the Figure 1, the maximum water that is retained in the depths of $0.0-0.10 \mathrm{~m}$ and $0.10-0.20 \mathrm{~m}$ is: $0.195 \mathrm{~cm}^{3} \mathrm{~cm}^{-3}$ and $0.221 \mathrm{~cm}^{3} \mathrm{~cm}^{-}$ ${ }^{3}$ respectively. It is observed that at the first depth the moisture in the field capacity is lower in relation to the second and at the wilting point, a fact justified by the high volume of pores $\left(0.415 \mathrm{~cm}^{3} \mathrm{~cm}^{-3}\right.$ with predominance of macropores) and soil texture, implying a faster drainage and greater evaporation, this reduces the water availability to the plants.

Considering that the drainage occurs from top to bottom starting in the larger pores, the available water content - TAW $(16.06 \mathrm{~mm})$ was smaller in the first depth $(0.0-0.10 \mathrm{~m})$, and higher macropores $\left(0,177 \mathrm{~cm}^{3} \mathrm{~cm}^{-3}\right)$ and possibly the at this depth (Table 2).

Table 2. Physical-water attributes of the soil Red-Yellow Alfisol, whose textural class is sandy-loam collected at depths of $0.0-0.10$ and $0.10-0.20 \mathrm{~m}$

\begin{tabular}{lcccccc}
\hline Depth (m) & $\begin{array}{c}\mathbf{\rho b} \\
\left(\mathbf{g ~ c m}^{-3}\right)\end{array}$ & $\begin{array}{c}\mathbf{\rho p} \\
\left(\mathbf{g ~ c m}^{-3}\right)\end{array}$ & $\begin{array}{c}\boldsymbol{\alpha} \\
\left(\mathbf{c m}^{\mathbf{3}} \mathbf{c m}^{-\mathbf{3}}\right)\end{array}$ & $\begin{array}{c}\text { Macrop. } \\
\left(\mathbf{c m}^{\mathbf{3}} \mathbf{c m}^{-3}\right)\end{array}$ & $\begin{array}{c}\text { Microp. } \\
\left(\mathbf{c m}^{\mathbf{3}} \mathbf{c m}^{-\mathbf{3}}\right)\end{array}$ & $\begin{array}{c}\text { TAW } \\
(\mathbf{m m})\end{array}$ \\
\hline $\mathbf{0 . 0}-\mathbf{0 . 1}$ & 1.51 & 2.58 & 0.415 & 0.177 & 0.237 & 16.06 \\
$\mathbf{0 . 1}-\mathbf{0 . 2}$ & 1.75 & 2.58 & 0.319 & 0.068 & 0.251 & 23.69 \\
\hline Mean & 1.63 & 2.58 & 0.367 & 0.123 & 0.240 & 19.88 \\
\hline Standard Dev & 0.175 & 0.0 & 0.067 & 0.077 & 0.009 & 5.401 \\
VC $(\boldsymbol{\%})$ & 10.7 & 0.0 & 18.4 & 62.8 & 3.9 & 27.1 \\
\hline
\end{tabular}

$\rho b$ e $\rho p$ : bulk density and particles; $\alpha$ : total porosity Macrop.: macroporosity; Microp.: microporosity; TAW: total available water; SD: standard deviation; VC: variation coefficient.

The available water content is a parameter of great importance for the plants, to infer about the volume of water available in the soil for the plants in the soil layer, such process is given by the water retention curve in the soil, in this case, it was observed in two layers. The AWC measured in millimeters is also of great value for irrigation, as the quantification of water at the time of irrigation.

Considering the importance and need for rational irrigation management, the total available water content (TAW) is a parameter obtained from soil sample (soil water characteristic curve), by concept, is the interval between the field capacity and wilt point, 
measured at $-10 \mathrm{kPa}$ and $-1.500 \mathrm{kPa}$, respectively, multiplying by the depth value in question to obtain the available water volume, taking into account the layer where most of the root system is located.

The amount of TAW depends on the texture and structure of the soil, that is, related to the water drainage velocity in the soil profile, in thesis, soils with clay texture will have higher water content than sandy ones. Therefore, the water retention capacity of a soil depends on the number and size of the pores, which are influenced by the texture, structure, organic matter and soil mineralogy (LOWERY et al., 1996).

The fact that the $0.10-0.20 \mathrm{~m}$ depth has a larger volume of available water $(23.69 \mathrm{~mm})$ is associated with a larger fraction of micropores $\left(0.251 \mathrm{~cm}^{3} \mathrm{~cm}^{-3}\right)$, as well as higher soil density $\left(1.75 \mathrm{~g} \mathrm{~cm}^{-3}\right)$. The fact that the density is higher and the volume of micropores in 0.20 $\mathrm{m}$ depth is higher are possibly related to the arrangement of the sand particles, due to a possible compaction caused by the use of the machines and implements used in the preparation of the experimental area for the sunflower cultivation, such as subsoil, plow and grade. According to Batey and Mckenzie (2006), compaction alters the soil structure, increases its density, decreases porosity, reduces air and water permeability, and consequently influences root growth.

Compaction reduces the pores diameter in the soil and its connectivity restricting the functioning of the porous network, thus, even if there is a good water volume in the layer, it does not mean that it is totally available to the plants, in this case, according to Lima et al. (2004), adsorbed water can dominates reducing its availability to the plants. It is worth mentioning that this type of behavior leads to low water storage in the soil profile, due to the fact that the water is retained with greater strength in the micropores, thus, it can cause water stress to the plants, depending on the cultivated plant.

\section{CONCLUSION}

The water in the soil cultivated with sunflower, at 80 days after irrigation cease, gradually drains in larger pores, then is retained in the pores of smaller diameter, these being possibly increased by the higher soil density, being able to limit the water availability to the plants within the soil layer, depending on the strength with which water is retained in the capillary pores.

\section{REFERENCES}

ACOSTA, J. F. Consumo hídrico da cultura do girassol irrigada na região da Chapada do Apodi - RN. 2009. 56 f. Dissertação (Mestrado em Engenharia Agrícola), Universidade Federal de Campina Grande, Campina Grande, 2009. Disponível em: <http://www.dca.ufcg.edu.br/posgrad_met/dissertacoes/JeanineFalconeAcosta_2009.pdf>. Acesso em: 05 ago. 2017. 
BATEY, T.; MCKENZIE, D. C. Soil compaction: identication directly in the field. Soil Use and Management, United Kingdom, v. 22, n. 3, p.123-131, 2006. Disponível em: <https://doi.org/10.1111/j.1475-2743.2006.00017.x>. Acesso em: 06 dez. 2016.

CARNEIRO, M. M. L, C. Trocas gasosas e metabolismo antioxidativo em plantas de girassol em resposta ao déficit hídrico. 2011. 42 f. Dissertação (Mestrado em Ciências) Universidade Federal de Pelotas, Pelotas, 2011. Disponível em: <http://guaiaca.ufpel.edu.br/handle/123456789/2043>. Acesso em: 15 dez. 2017.

CASTRO, C.; BOUÇAS, F. J. R. Ecosfisiologia do girassol. In: LEITE, R. M. V. B. C., BRIGHENTI, A. M., CASTRO, C. (Eds.). Girassol no Brasil. Londrina: EMBRAPA Soja, 2005. cap. 3, p. 163-218.

COSTA, W. A.; OLIVEIRA, C. A. S.; KATO, E. Modelos de ajuste e métodos para a determinação da curva de retenção de água de um Latossolo Vermelho-Amarelo. Revista Brasileira de Ciência do Solo, Viçosa, v. 32, n. 2, p. 515-523, 2008. Disponível em: <http://dx.doi.org/10.1590/S0100-06832008000200006>. Acesso em: 07 out. 2017.

DANIELSON, R. E.; SUTHERLAND, P. L. Porosity. In: KLUTE, A. (eds.). Methods of soil analysis. 2. ed. Madison, EUA: American Society of Agronomy, Soil Science Society of America, 1986. cap. 2, p. 443-461.

DEXTER, A. R. Soil physical quality. Part II. Friability, tillage, filth and hard-setting. Geoderma, The Netherlands, v. 120, p.215-225, 2004. Disponível em: <10.1016/j.geoderma.2003.09.005>. Acesso em: 14 out. 2017.

EMPRESA BRASILEIRA DE PESQUISA AGROPECUÁRIA - EMBRAPA. Sistema Brasileiro de Classificação de Solos. 3 ed. Rio de Janeiro, RJ: Embrapa Solos, 2013. 353 p.

EMPRESA BRASILEIRA DE PESQUISA AGROPECUÁRIA - EMBRAPA. Manual de métodos de análise de solo. Rio de Janeiro, RJ: Embrapa Solos. 2011, 230 p.

EMPRESA BRASILEIRA DE PESQUISA AGROPECUÁRIA - EMBRAPA. Sistema de produção do girassol para as mesorregiões do agreste paraibano e da mata paraibana. João Pessoa, PB: EMBRAPA, 2007, 17 p.

GOMES, E. M.; UNGARO, M. R. G.; VIEIRA, D. B. Impacto da suplementação hídrica no acúmulo e partição da matéria seca de girassol. In: SIMPÓSIO NACIONAL DE GIRASSOL, 3, Ribeirão Preto, 2003. Anais... Ribeirão Preto: CATI, 2003. CD-ROM.

LEITE, R. M. V. B. C. Doenças do girassol (Helianthus annuus L.). In: KIMATI, H.; AMORIM, L.; BERGAMIN FILHO, A.; CAMARGO, L. E. A.; REZENDE, J. A. M. Manual de Fitopatologia. 4. ed. São Paulo, SP: Agronômica Ceres, 2005. cap. 56, p. 385400. 
LIMA, H. V.; SILVA, A. P.; JACOMINE, P. T. K.; ROMERO, R. E.; LIBARDI, P. L. Identificação e caracterização de solos coesos no estado do Ceará. Revista Brasileira de Ciência do Solo, Viçosa, v. 28, n. 3, p.467-476, 2004. Disponível em: <http://dx.doi.org/10.1590/S0100-06832004000300008>. Acesso em: 25 set. 2017.

LIMA JÚNIOR, J. A.; PEREIRA, G. M.; GEISENHOFF, L. O.; COSTA, G. G.; REIS, R. P.; OLIVEIRA, L. F. C. Avaliação econômica da produção de alface americana em função de lâminas de irrigação. Ciência e Agrotecnologia, Lavras, v. 35, n. 2, p.392-398, 2011. Disponível em: <http://dx.doi.org/10.1590/S1413-70542011000200022>. Acesso em: 03 out. 2016.

LOWERY, B. Soil water parameters and soil quality. In: DORAN, J. W.; JONES, A. J. (Eds.). Methods for assessing soil quality. Madison, EUA: SSSA Spec., 1996. cap. 3, p.143155.

MANTOVANI, E. C.; BERNARDO, S.; PALARETTI, L. F. Irrigação: princípios e métodos. Viçosa: Ed. UFV, 2009. 355 p.

MELO, D. V. M.; ALMEIDA, B. G.; SOUZA, E. R.; SILVA, L. S.; JACOMINE, P. K. T. 2014. Structural quality of polyacrylamide-treated cohesive soils in the coastal tablelands of Pernambuco. Revista Brasileira de Ciência do Solo, Viçosa, v. 38, n. 2, p.476-485, 2014. Disponível em: <http://dx.doi.org/10.1590/S0100-06832014000200012〉. Acesso em: 17 dez. 2017.

MENEZES, A. S.; ALENCAR, T. L.; ASSIS JÚNIOR, R. N.; TOMA, R. S.; ROMERO, R. E.; COSTA, M. C. G.; MIGUEL, C.; MOTA, J. C. A. Functionality of the porous network of Bt horizons of soils with and without cohesive character. Geoderma, The Netherlands, v. 313, n. $1, \quad$ p.290-297, $2018 . \quad$ Disponível em: <https://doi.org/10.1016/j.geoderma.2017.11.005>. Acesso em: 09 jan. 2018.

REICHARDT, K.; TIMM, L. C. Solo, planta e atmosfera: conceitos, processos e aplicações. Barueri: Ed. Manole, 2012. 500 p.

SILVA, M. L. O. E.; FARIAS, M. A.; MORAIS, A. R.; ANDRADE, G. P.; LIMA, E. M. C. Crescimento e produtividade do girassol cultivado na entressafra com diferentes lâminas de água. Revista Brasileira de Engenharia Agrícola e Ambiental, Campina Grande, v. 11, n. 5, p.482-488, 2007. Disponível em: 〈http://www.scielo.br/pdf/rbeaa/v11n5/v11n05a06.pdf〉. Acesso em: 05 nov. 2017.

SILVA, A. P.; KAY, B. D.; PERFECT, E. Characterization of the least limiting water range of soils. Soil Science Society of America Journal, Madison, v. 58, n. 6, p.1775-1781, 1994. Disponível em: <doi:10.2136/sssaj1994.03615995005800060028x>. Acesso em: 03 set. 2017.

SOUZA, I. H.; ANDRADE, E. M. Manejo da irrigação. In: ANDRADE, E. M.; PEREIRA, O. J.; DANTAS, F. E. R. (Eds). Semiárido e manejo dos recursos naturais: uma proposta de uso adequado do capital natural. Fortaleza: editora Universitária, 2010. cap. 2, p. 239-260.

TORMENA, C. A.; SILVA, A. P. Incorporação da densidade no ajuste de dois modelos à curva de retenção de água no solo. Revista Brasileira de Ciência do Solo, Viçosa, v. 26, n. 
2, p.305-314, 2002. Disponível em: 〈http://www.scielo.br/pdf/rbcs/v26n2/03.pdf>. Acesso em: 03 set. 2017.

TULLER, M.; OR, D. Waterfilms and scalingofsoilcharacteristic curves atlowwatercontents. Water Resources Research, Singapore, v. 41, n. 1, p.01-06, 2005. Disponível em: <https://doi.org/10.1029/2005WR004142>. Acesso em: 03 set. 2017.

VIANA, T. V. A.; LIMA, A. D.; MARINHO, A. B.; DUARTE, J. M. L.; AZEVEDO, B. M.; COSTA, S. C. Lâminas de irrigação e coberturas do solo na cultura do girassol, sob condições semiáridas. Irriga, Botucatu, v. 17, n. 2, p.126-136, 2012. Disponível em: <http://irriga.fca.unesp.br/index.php/irriga/article/viewFile/505/265>. Acesso em: 08 dez. 2017. 